\title{
INSIGHTS ON THE EMERGENCE AND CONCEPTUAL EVOLUTION OF COASTAL GEOGRAPHY IN FRANCE.
}

\section{APERÇUS SUR L'EMERGENCE ET L'ÉVOLUTION CONCEPTUELLE DE LA GÉOGRAPHIE CÔTIÈRE EN FRANCE}

\author{
ELLY HERMON ${ }^{1}$ \\ elly.hermon@hst.ulaval.ca
}

\begin{abstract}
The paper provides an analytical overview of significant landmarks in the conceptual evolution of coastal geography in France since its emergence in the early 1950s. The paper comprises four sections dealing respectively with the following themes:

1. The conceptual trajectory of this field of study which resulted in significant broadening of its scope and methodology with the integration of physical geography and human geography dealing with coastal issues, which brought to adoption of a systemic approach and a broad vision characterizing global geography;

2. The remarkable complexity of the coastal space as reflected by the complex interactions between society and the natural environment and the resulting implications for the definition of this space;

3. The growing involvement of coastal geographers in management of the coastal space and the significance of their contribution to adopting an integrated management approach intended to advance sustainable development of coastal areas affected by rapidly increasing anthropization and natural forces with adverse impacts such as shoreline erosion and rising sea level;

4. The coastal vulnerability and environmental risk management, stressing the need for an appropriate land use planning.
\end{abstract}

KEY WORDS: coastal anthropization; sea level rise; coastal vulnerability; coastal risk management; integrated coastal management.

\footnotetext{
${ }^{1}$ Formerly researcher at Laval University. Avenue des Sciences Humaines, Université Laval, Québec, (Qc) - G1V 0A6, CANADA.

E. HERMON, "Insights on the emergence and conceptual evolution of coastal geography in France", RIPARIA 0 (2014), 125-149. 


\section{RÉSUMÉ}

L'article offre un aperçu de l'évolution conceptuelle du domaine de la géographie du littoral en France dès son émergence au début des années 1950. Il inclut quatre sections portant respectivement sur les thèmes suivants:

1) La trajectoire conceptuelle qui aboutit à un développement significatif de la portée et de la méthodologie de ce domaine d'étude avec l'intégration de la géographie physique et de la géographie humaine s'occupant de questions relatives aux littoraux: vers l'adoption d'une approche systémique et d'une large vision propre de la géographie globale:

2) La complexité remarquable de l'espace littoral reflétée par les interactions entre la société et le milieu naturel et les implications qui en résultent pour la définition de cet espace.

3) L'implication croissante des géographes des littoraux dans la gestion de l'espace littoral et l'importance de leur contribution à l'adoption de l'approche de gestion intégrée pour l'avancement du développement durable: impacts de l'anthropisation et de facteurs naturels tels que l'érosion de la ligne côtière et l'élévation du niveau de la mer;

4) La vulnérabilité de l'espace littoral et la gestion du risque environnemental: la nécessité d'une gestion appropriée de l'occupation du sol.

MOTS - CLÉ : anthropisation de l'espace côtier; élévation du niveau de la mer; vulnérabilité de l'espace littoral; gestion intégrée du littoral 
RIPARIA VOL. 0 (2014)

From physical geography to global geography: the conceptual trajectory of coastal geography in France.

This paper aims at providing an analytical overview of the emergence and conceptual evolution of coastal geography in the past decades in France in the light of contributions and insights provided by distinguished French geographers associated with this field of study. The complexity and relatively rapid evolution of coastal geography in France in the second half of the $20^{\text {th }}$ century does not facilitate the definition of this dynamic field, which explains the presence of a number of such definitions varying from each other by nuances reflecting evolving visions of this field of study as regards its object, scope and priorities.

The following recent definition shades light on the object and scope of this field of study as conceived of in a rather advanced stage in this evolution:

"Coastal geography is the study of the dynamic interface between the ocean and the land, incorporating both the physical geography (i.e. coastal geomorphology, geology and oceanography) and the human geography (sociology and history) of the coast. It involves an understanding of coastal weathering processes, particularly wave action, sediment movement and weather and also the ways in which humans interact with the coast"2.

This definition tends to reflect current research interests of this field of study which has undergone in France a very significant evolution in the past decades since World War II and the analysis of which is the object of this paper.

André Guilcher (1913-1993), a prominent French geographer, largely considered as the founder of the French influential school of coastal geography, played a major role in orienting this field of study towards covering a wide range of

2 http://en.wikipedia.org/wiki/Coastal geography (17/08/2014). 
coastal issues while pointing out their interrelationships. In a widely appreciated essay entitled "Towards a Philosophy of Seashores"” he provides an insight into the evolution of coastal geography, stressing an advancement reflecting his own approach to this field of study which incorporates, besides the reorientation of its academic scope, a call for protecting the fragile coastal areas. Accordingly, he emphasizes the rapidly growing human pressure on coastal zones, occurred in the second half of the $20^{\text {th }}$ century for two main reasons: a) the enormous growth of maritime commerce, the growing size of transportation vessels and port facilities; b) the massive development of the leisure industry entailing an increased human pressure on seashores with the resulting competition between various sectors interested in developing their activities in these areas: maritime commerce, port activities, fishing, tourism, agriculture; including nature lovers with a special interest in nature conservation.

In the context of increased human pressure on coasts, scientific information about increased and rapid erosion of seashores was given increased attention. This information indicated that, in the few decades following WWII, about 70 percent of the sandy coastlines were affected by significant erosion ${ }^{4}$, a process attributed notably to the depletion of the sediment stocks contributing to sand build-up in seashores, and to sea level rise caused by global warming resulting also from emissions of greenhouse gases related to human activities. It was thus the combination of natural and anthropic factors which in Guilcher's view explained their increased adverse impacts on coastal areas and stimulated efforts aimed at their protection. Concomitantly, he recognized the complexity of the challenge of searching appropriate solutions and the need for dealing with the problems affecting these areas on a one by one basis rather than

3 A. Guilcher, "Vers une philosophie des rivages", Cabiers Nantais 35-36,1990, 3-15.

${ }^{4}$ E.C.F. BIRD, Coastline Changes, A Global Review, Chichester 1985 cited by GuILCHER, "Vers une philosophie ...", 4.

"Insights on the emergence and conceptual evolution of coastal geography ..." 
through the search of an overall solution. He emphasized his preference for specific solutions taking fully into account the local constraints or more specific causes contributing to recession of coastlines - such as impacts of various human activities (extraction activities, inappropriate land use, etc.) -, while still recognizing the significance of general causes, like those above-mentioned, of this phenomenon. Accordingly, he strongly opposed indiscriminate human interventions intended to advance inappropriate land use, such as residential building activities in shoreline areas largely exposed to adverse impacts of the environment, by coastal engineering artificially modifying the coastline. Yet, he recognized that in some cases such works were reasonable given the importance of some human activities, such as port activities playing a significant economic role and which for some imperative reason could hardly be displaced elsewhere ${ }^{5}$.

Guilchers's academic and intellectual evolution as a geographer is of special interest here given his contribution to the emergence and evolution of coastal geography in France. His scientific itinerary is all the more of interest here as it reflects to à large extent that of numerous French geographers, many of whom his own students or the latter's students inspired by his work. He made his first significant steps in the study of coastal issues in the early 1950s as physical geographer. His 1954 study on coastal and underwater morphology ${ }^{6}$ was defined as a classic text on this subject by Roland Paskoff (1933-2005) - who, like Guilcher himself, had made his first steps in the academia as a physical geographer and due to his growing interest in coastal geography became a distinguished scholar in this field of study. Paskoff referred to the cited Guilcher's study as an illustration of the still dominant position of physical geography in the early 1950s within the emerging issue area of coastal geography. In a retrospective study, published decades later about the contribution of French

\footnotetext{
5 A. Guilcher, "Vers une philosophie...", 8-10.

${ }^{6}$ A. GuILCHER, Morphologie littorale et sous-marine, Paris 1954.
} 
physical geographers to the development of coastal geography, he stressed the total mutual impermeability characterizing the relationships at that period (the early 1950s) between the field of physical geography and that of human geography, at this early stage in the evolution of coastal geography ${ }^{7}$. This situation changed markedly in the following decades when it was realized that by their growing rush to coastal areas, humans have become important agents of change of these fragile areas, though this has often happened unintentionally. They failed to foresee the significant adverse impacts of their imprudent interventions in the coastal environment which frequently contributed to destabilizing the fragile equilibriums characterizing the natural dynamic processes occurring in these fragile areas. The publication of Paskoff's book about the impacts of land use planning in coastal areas in $1985^{\circ}$ provided a clear indication of the new trend encouraging the incorporation of both branches - physical geography and human geography - into the developing field of coastal geography. This reflected a growing understanding of the need for protecting the coasts against adverse impacts of natural factors - dealt with by physical geography - as well as of human activities - the object of human geography. This involved a reconsideration of an older geographical approach less characterized by differentiation between specialized branches of geography, which led to the emergence of "global geography" based on the study of human activities impacting their environment and natural processes impacting the latter in an interactive manner which is all the more significant in the light of the currently growing complexity and vulnerability of coastal areas?.

\footnotetext{
7 R. PASKOFF, "La contribution des géographes naturalistes à la géographie des littoraux", Océans 28(1-2), 2002, 27-38.

8 R. PASKOFF, Les littoraux, impacts des aménagements sur leur évolution, Paris 1985.

9 R. PASKoff, "La contribution des géographes...", 28; A. Miossec, Les littoraux entre nature et aménagement, Paris 1998.
}

"Insights on the emergence and conceptual evolution of coastal geography ..." 
Catherine Meur-Férec - a well-established scholar of a younger generation of French geographers with a strong interest in coastal issues -, while recognizing her intellectual indebtedness to Guilcher and Paskoff, followed an intellectual trajectory similar to theirs by evolving from the study of geomorphology towards "global geography". Commenting her research record, she provided a functional definition of its object - the coastal space described as "a multiple interface between sea and land, nature and society, policies and practices" ${ }^{10}$, a definition highlighting the significance of the interactions between the various components physical and social - of this complex system. Focusing much of her research on social issues within the scope of coastal geography, she adopted however a position she qualified as anthropocentric, which raises some questions, although it may be shared by other geographers. Accordingly, nature conservation, important as it is in coastal zones where the vulnerability of the natural environment to adverse impacts of human activities is particularly high, must be linked to the human condition; out of this context nature per se would have no rights ${ }^{11}$. One may wonder to what extent this view is compatible with the global geography approach and its underlying assumptions as to Man-Nature relations, and more particularly with the integrated management approach applied to coastal zones and beyond, on which incidentally much of MeurFérec's own work is focused ${ }^{12}$, where the significance of the interactions between society and the natural environment is widely recognized. The issue of nature conservation remained controversial among practitioners of coastal management in

\footnotetext{
10 C. MEur-FÉREC, De la dynamique naturelle à la gestion intégrée de l'espace littoral. Un itinéraire de géographe, Université de Nantes (HDR), 2006.

http://hal.archives-ouvertes.fr/docs/00/16/77/84/PDF/essai inedit Meur-Ferec.pdf (30/07/2014).

11 C. MEur-FÉREC, De la dynamique naturelle..., 213.

12 Ibid., 13, 16.
} 
France to the point of hindering the implementation of coastal management policies $^{13}$.

Jean-Pierre Pinot was another distinguished French geographer, specialized in physical geography, who under the influence of A. Guilcher came to strongly support the integration of both physical geography and human/social geography into the developing field of coastal geography. In an important retrospective essay on the evolution of this field in France, published in $2002^{14}$, Pinot argues that only in the $20^{\text {th }}$ century advances in the reflection about the fundamental objectives of geography allowed the recognition of the three following ones as the basic aims of what he names "sea and coastal geography": a) description of the places; b) understanding of the functioning of the mechanisms governing their evolution; c) using this understanding to reduce the undesirable impacts of their instability. The emphasis placed on instability as a major characteristic of the coastal environment supports Pinot's view that given the special nature of the coastal space as a mobile and interactive interface between land and water, the above-mentioned desired understanding cannot be attained without abolishing the separation between two major branches of geography dealing with coastal zones - that dedicated to the study of the land and that focused on the study of the sea, a centuries- long separation reduced only in the $20^{\text {th }}$ century. Another fundamental separation between two other main branches of geography dealing with coastal zones, the abolishment of which is described as being much needed as well, is that between physical geography and human/social geography, both integrated in into the developing field of coastal geography in the second half of the $20^{\text {th }}$ century. Pinot argues that keeping apart these two branches of geography

\footnotetext{
13 A. Miossec, "Aménagement et milieux naturels: le littoral français entre ruptures et continuités”, Cabiers Nantais 47-48, 1997, 397.

14 J.-P. PINOT, "Géographie des littoraux en France: évolution d'une discipline”, in Le littoral, regards, politiques et savoirs. Études offertes à Fernand Verger, Paris 2002, 27-58.
}

"Insights on the emergence and conceptual evolution of coastal geography ..." 
is misguided all the more that in the case of coastal zones their complementarities are obvious even more than in other regions, a reference to the higher intensity of the interactions between society and the natural environment in coastal zones. He praises, once again, the leading role played in this regard by A. Gulicher. He also stresses the latter's contribution to the advancement of interdisciplinarity in the field of coastal geography, highlighting his strong interest in developing collaboration between geologists and scholars of coastal geomorphology like himself. This approach reflects his view that the study of underwater morphology, one of his early areas of special interest, is necessary for advancing the understanding of coastal morphology ${ }^{15}$.

It should be noted however that though Guilcher strongly promoted the unification of coastal geography, encouraging integrating into it various relevant areas of study, he did not underestimate the high degree of its diversity, of which Pinot himself was well aware ${ }^{16}$.

\section{The definition of coastal space in the light of the interactions between society and the natural environment.}

As stated by Meur-Férec, any geographical approach centered on the study of a specific kind of space must provide first a clear definition of that space, which is all the more relevant, yet difficult to produce in the case of a complex space like the coastal space. The high degree of complexity of this space, apparently explains the existence of a variety of definitions of coastal space offered by scholars, including geographers, from different fields

15 J.-P. PINOT, “Géographie des littoraux...”, 49.

16 Pinot identified five branches in the field of "sea and coastal geography": physical geography, human geography, regional geography, development of relevant techniques (i.e. topography, sedimentology, remote sensing, thematic cartography, management of the natural environment) and recognised that a scholar by himself alone was unable to master all, or even most, of its diverse branches. He advocated therefore team work and collaboration among scholars from different areas. J.-P.PINOT, "Géographie des littoraux...", 54-58. 
dealing with coastal issues. A main difficulty for producing an agreed-upon clear definition derives from the fluctuating nature of this space - an interface between sea and land susceptible to move a short distance to either side - which makes its delimitation uncertain. Accordingly, jurists for instance prefer to define this space pending the specific issue dealt with, whereas geographers tend to avoid its delimitation given its dynamic and mobile nature, while still differentiating between coastal space restricted to the intertidal zone and littoral space comprising adjacent landforms such as dunes ${ }^{17}$.

According to Alain Miossec, another distinguished French geographer who contributed significantly to the advancement of coastal geography in France, the difficulties regarding the definition of coastal space related to its uncertain delimitation, transcend the academic debate and have hindered the implementation of coastal management schemes in France for decades. Another reason of these difficulties was hesitation about the place of Nature in the decision-making process ${ }^{18}$.

This reference to the role of society in the characterisation of the coastal space is a significant step towards its definition as a highly complex system, the dynamic nature of which being determined to a large extent by the interactions between society and the natural environment. It was this broad vision of the coastal space which brought to its definition as an eco-socio-system ${ }^{19}$ adopted in a 1997 UNESCO document aimed at providing methodological guidance for advancing integrated management of coastal zones, where appears the following statement:

\footnotetext{
17 C. Meur-FÉREC, De la dynamique naturelle..., 34.

18 A. Miossec, “Aménagement et milieux naturels... ”, 397.

19 On the elaboration of this concept see J.-P. CORLAY, "Géographie sociale, géographie du littoral", Norois 42 (165), 251-253.
}

"Insights on the emergence and conceptual evolution of coastal geography ..." 
RIPARIA VOL. 0 (2014)

"So as to be able to manage and develop coastal zones in a sustainable manner decision-makers must understand how the natural environment and human activities interrelate to form an "eco-socio-system" which may be analyzed through a study of its inherent elements: natural processes which interact with socio-eco-systems; resources used by Man; current and future conflicts which result from them" 20 .

The adoption of the definition of the coastal space as an eco-socio-system by the international community marks a landmark in the conceptual evolution of a field of study which in a period no longer than a few decades, gained a status higher than just a mere branch of the discipline from which it emerged. This was achieved notably due to the remarkable complexity of its object of study and the global vision of its broadening scope which allowed the coherent development of various areas of study within this field. A significant factor in this regard was the special nature of its object of study - a space, singular from many perspectives, which provided a fertile, multidimensional and open-ended field of scientific research encouraging contributions of diverse areas of study. The remarkably broad scope of the field named coastal geography, which integrates perspectives and methods of many areas of study in natural, social and human sciences, confers it a rather special status, different that of a conventional scientific discipline, being characterized by a strong interdisciplinary orientation reflecting its broad vision of the interactions between society and the natural environment and of their significance in determining its scope. The recognition of the significance of ManNature interactions in coastal geography appears thus as an a outcome of the conceptual evolution of this field which brought to the definition of its object of study, the coastal space, as an ecosocio-system, the complexity of which calls for adoption of a systemic approach to scientific investigation with significant

20 UNESCO, Methodological Guide to Integrated Coastal Management, Intergovernmental Oceanographic Commission, Manual and Guides No.36, 1997. 
applications for the management of this dynamic and vulnerable space.

\section{From empirical management to integrated management of the coastal space.}

The coastal space has been throughout Antiquity an object of observation, characterization and reflection which allowed the identification of its main characteristics: instability, change, imprevisibility. Concomitantly, though often leaving only scarce clear traces in the written documents of the period, there was a growing awareness of the society regarding the risks and inconveniences of exploiting this space so attractive for humans and of the need for addressing them. This gave rise to an empirical management of the coastal space, evidenced notably by significant archaeological findings as well as by some documentary sources such as those related to Roman law which dealt with various waterside management issues, including coastal ones ${ }^{21}$. This led notably to the adoption of some practical defensive measures aimed at reducing the inconveniences of the instability of the coastal space. Antiquity left thus quite significant traces of various installations and measures used for this purpose which show that the Ancients had a significant geographical empirical knowledge though they lacked the deeper understanding, possessed by modern geographers, of the natural processes and their interaction with human activities. The approach based on an empirical management of the coastal space prevailed thus throughout the pre-modern era through the works realized by practitioners of this type of management, notably engineers and seamen, who were not oriented by a general scientific theory but by rather personal insights, rarely expressed by writing, into the functioning of the natural mechanisms governing the complex coastal environment ${ }^{22}$.

21 E. Hermon (dir.), Riparia dans l'empire romain, pour la définition du concept, Oxford 2010, E. Hermon, A. WATELET (dir.), Riparia, un patrimoine culturel. La gestion intégrée des bords de l'eau, Oxford 2014.

22 J.-P. PINOT, “Géographie des littoraux...”, 34-37.

"Insights on the emergence and conceptual evolution of coastal geography ..." 
As to geographers, prior to the modern era they preferred to keep silent about theoretical issues related to explanation of the natural processes affecting the coastal environment and the impacts of human activities on it. In the modern era, once again, practitioners were the first to deal with such issues as impacts of tourism on this environment, dealt at first with in travel writings rather than in geographical texts, whereas geographers tended to avoid general conclusions as long as they could not base them on complete and reliable relevant information ${ }^{23}$. They became gradually involved in coastal management only in the course of the $20^{\text {th }}$ century, when such information became available and allowed a global understanding of the natural and human mechanisms/processes and their interactions affecting coastal areas. Commenting the repercussions of this involvement of geographers in coastal management, Jean-Pierre Pinot argues that geographers are faced basically with two options: either acting on the natural component of the coastal system, or acting rather on its social component. In both cases their interventions are aimed at reducing the risks inherent to the coastal system, the functioning of which being determined by both components and their interactions. He decries interventions of managers who are not geographers (and consequently lack the understanding and motivation of the latter) and who opt for easy and rather unhelpful interventions, masking the reality by "cosmetic" operations providing only an illusion of dealing efficiently with the risk factors, and which nevertheless are quite frequently used in France. Pinot argues emphatically that geographers must base their interventions in coastal management on a different approach taking fully into consideration the relationships between the two basic components - the natural and the social - of this issue area and opposing the "cosmetic temptation" 24 .

${ }^{23}$ Ibid., 38.

24 J.-P. PINOT, “Géographie des littoraux...”, 42. 
The involvement of academic geographers in coastal management in France grew markedly since the 1970s with the multiplication of governmental coastal management schemes, and their contribution to preliminary studies conducted in this framework was significant. The improved understanding of the natural processes and fragility of coastal ecosystems, produced by these studies, highlighted the human-induced increasing erosion of coastal areas and the adverse impacts of their abusive urbanization, including large zones (such as maritime marshes, dunes) considered sterile rather than natural components of a fragile ecosystem. The information produced by such studies tended to support, though not decisively, environmentalist ideas associated with the sustainable development approach opposed to uncontrolled development of the fragile coastal zones ${ }^{25}$.

The growing involvement of geographers in coastal management was highlighted by A. Guilcher in an essay, published in 1987, where this tendency is described as a general trend. Accordingly, faced with the challenges of protecting the coastal environment increasingly affected by adverse impacts of human activities, coastal geographers tended to become actors rather than mere observers. Although they still remained active in the area of basic research as well, they were showing a growing interest in applying their scientific expertise for interventions aimed at maintaining or restoring an optimal equilibrium in adversely affected coastal zones. In France, geographers were encouraged to reorient themselves accordingly by legislation passed in 1986 with a view to protecting coastal zones in line with the sustainable development approach attempting to conciliate environmental protection and economic development ${ }^{26}$.

25 A. Miossec, “Aménagement et milieux naturels...”, 397-398.

26 A. Guilcher, "Développement de la notion de gestion des littoraux chez les géographes français", in Régions, villes et aménagement. Mélanges jubilaires offerts à J. BeaujeuGarnier, Paris 1987, 565.

"Insights on the emergence and conceptual evolution of coastal geography ..." 
RIPARIA VOL. 0 (2014)

The French geographers' growing involvement in coastal management produced some significant results pointed out by A. Guilcher ${ }^{27}$. These included interventions aimed to conserve natural environment in coastal zones which, due their high interest as an object of scientific research, to deserved special protection. Geographers managed thus to combine management objectives and advancement of basic research in coastal geography. This tendency is of special interest as it highlights the intrinsic value attributed to nature by many geographers who appear thus to be, at least in some cases, on the front line of nature conservation in coastal zones. Their support of nature conservation apparently contributed to the adoption of some significant measures in this regard, such as the creation in 1975 of the Conservatoire du littoral - a public organism unparalleled in other countries and dedicated to the protection of Nature in particularly fragile and threatened coastal (and other waterside) areas by acquiring land where nature was (and still is) given appropriate protection involving also orienting human activities in a manner compatible with this protection $^{28}$.

This initiative which involved local communities in the management of the land acquired by the Conservatoire may therefore be considered as a significant step towards advancing adoption of the integrated management approach in coastal zones. Another indication of this evolution in the academic sphere is the tendency to combine management objectives including protection of the environment with basic research on coastal issues, as reflected in the scientific literature produced by geographers in the referred to period. An illustration of this tendency is a study published in 1985 by Roland Paskoff where geomorphological description is combined with analysis of human impacts on different types of

27 Ibid., 566.

28 Conservatoire du littoral - http://fr.wikipedia.org/wiki/Conservatoire du littoral (30/08/2014). 
coastal forms ${ }^{29}$. An illustration of the development of this research area is an interdisciplinary research project (1985), associating geographers, biologists and jurists coordinated by the noted coastal geographer Alain Miossec, which provides a multidimensional analysis of a specific French coastal zone, including geomorphological, environmental and land use issues ${ }^{30}$.

These endeavours reflected the rise, observed in the early 1970s, of an influential opinion stream favourable to adopting more environmentally-friendly policies, which led to the creation of the French Ministry of the Environment. This resulted in a growing denunciation - shared by noted French coastal geographers such as A. Guilcher, J.-P. Pinot, R. Paskoff, A. Miossec and many others - of an abusive economic development mutilating landscapes and notably the most fragile environments such as the costal space. Commenting this process of value change occurring in the French society, A. Miossec indicated also the resistance to this change opposed by those remained faithful to the old anthropocentric values considering Nature as a domain to be conquered by Man including through unsustainable practices such as intense tourism activities in fragile coastal areas. He also indicated the allegedly paradoxical attitude of the French authorities in this regard: while attempting to bring to a value change in the conception of nature, compatible with a more environment-friendly vision, they still applied centralized policies unfavourable to involvement of local communities in the management of their environment in accordance with the integrated management of coastal zones, which he strongly advocated $^{31}$.

The tendency to combine management objectives including protection of the environment with basic research on

\footnotetext{
29 R. PASKofF, Les littoraux. Impact des aménagements sur leur évolution, Paris 1985.

30 A. GuILCHER, "Développement de la notion de gestion... ", 567.

31 A. Miossec, "Aménagement et milieux naturels...", 400.
}

"Insights on the emergence and conceptual evolution of coastal geography ..." 
coastal issues was reflected in the scientific literature produced by geographers in the referred to period. An illustration of this trend is a study published in 1985 by Roland Paskoff where geomorphological description is combined with analysis of human impacts on different types of coastal landforms ${ }^{32}$. Competing uses of costal space are another research theme given special attention in this period by coastal geographers. An illustration of the development of this research area is an interdisciplinary research project (1985), associating geographers, biologists and jurists and coordinated by the noted coastal geographer Alain Miossec, which provides a multidimensional analysis of a specific French coastal zone, including geomorphological, environmental and land use issues $^{33}$.

The gradual involvement of geographers in coastal management was not an easy process. For a long time, practitioners in charge of developing the coastal space (rather than managing it, still ignoring the integrated management approach, largely adopted only towards the end of the $20^{\text {th }}$ century) have been oriented just by their own experience or by engineering principles. There was no interaction between them and geographers whose expertise remained unsolicited. Consequently, the practitioners' interventions have often produced poor results as they were not oriented by an appropriate understanding of the functioning of the coastal system possessed by geographers, who anyhow considered it as still incomplete and hesitated to offer their collaboration. Eventually, the area of applied geography had been initially developed in France by specialists of human geography and only about 20 years later coastal geographers began dealing with coastal management issues ${ }^{34}$. It took however two devastating oil spill disasters (those of Torrey-Canyon in 1967 and Amoco-Cadiz in 1978) to decide geographers to offer their collaboration and

\footnotetext{
32 R. PaskofF, Les littoranx ...

33 A. Guilcher, "Développement de la notion...", 56.

34 J.-P. PINOT, "Géographie des littoraux...”, 31.
} 
decision-makers to hid their advice. Previously, management of coastal areas had been rather the exclusive domain of practitioners seeking to artificially adapt coastal areas to their use rather than adapting land-use to the natural dynamics of the coast. These two approaches reflected two different conceptions of coastal management: that of engineers, based on resisting the assaults of the sea by erecting coastal defence structures, and that, milder, of geographers seeking to use natural mechanisms for the desired defensive purposes. According to J.-P. Pinot, geographers became involved in coastal management too late since much irreversible damage to French coastal areas had been done previously, mostly in the first half of the $20^{\text {th }}$ century ${ }^{35}$. However, a few decades later, the geographers' involvement in coastal management became part of their regular tasks as applied geography became integrated in coastal geography. This resulted from an improved understanding of the natural processes affecting coastal areas as well as the social aspirations regarding them, which facilitated reaching a higher degree of harmony between environmental protection and stakeholders' aspirations. Pinot laments however the unequal progress achieved in these two areas: while improving significantly their understanding of the coastal environment, geographers failed to achieve similar progress in reorienting the aspirations of dominant interest groups whose influence hindered the implementation of French and European coastal management policies seeking to improve environmental protection of the coasts $^{36}$.

\section{Perspectives on challenges of sea level rise and coastal vulnerability.}

The relevance of the issue area of sea level rise, its causes and impacts, has significantly increased over the past few decades as coastal vulnerability to these impacts grew with the rapidly growing anthropization of the coasts. Consequently, it has become

\footnotetext{
35 Ibid., 32.

36 Ibid., 33.
}

"Insights on the emergence and conceptual evolution of coastal geography ..." 
a major theme of reflection for coastal geographers. Some glimpses of the evolution of this reflection are provided by the proceedings of a conference held in 2000 (Arles, France) on impacts of climate change on coastal areas in various countries and various coastal environments (deltas, estuaries, lagoons, marine marshes, beaches, coral reefs, mangroves) focusing on risks and social responses to rising sea level ${ }^{37}$. The conference, supported by the French interdepartmental committee on the greenhouse effect and attended by noted coastal geographers - such as R. Paskoff (chairman of the organizing scientific committee), F. Verger, A. Miossec, P.A. Pirazzoli -, dealt with the various environmental and socio-economic aspects of and responses to global warming induced rising sea level. In his introduction to the conference proceedings, R. Paskoff mentioned the uncertainties surrounding measuring global worming induced sea level rise given the interference of factors related to specific local environments, a point stressed by Fernand Verger who argued that "effects of global sea rise are expected to be variable, especially on law alluvial coasts bordered by shallow waters" 38 . Accordingly, sea level is determined not only by global climate influence but also by the volume of sediments transported by rivers to their mouth and which in many cases diminish considerably (e.g., estimated $96 \%$ in the case of the Ebro river) due to human interventions such as dyke construction and water withdraws for irrigation purposes ${ }^{39}$.

Prevision of future climate evolution is an additional factor of uncertainty. Similar uncertainties surround also the impacts of sea level rise and should be taken into account as well in preparing adequate social responses. These responses have to be determined

\footnotetext{
${ }^{37}$ R. PASKOFF (coord.), Le changement climatique et les espaces côtiers. L'élévation du niveau de la mer: risques et réponses. Actes du colloque d'Arles, 12-13/10/2000, Paris 2001.

38 F. VERGER, "Les risques liés à l'élévation du niveau de la mer dans les marais maritimes et les polders", in R. PASKOFF (coord.), Le changement climatique..., 20.

39 R. PASKOFF, "Le changement climatique, l'élévation du niveau de la mer et les espace côtiers: synthèse et perspectives", in R. PASKOFF (coord.), Le changement climatique ...
} 
by a variety of considerations - economic and social stakes, financial cost, perceptions or collective psychology - which should orient adopting the response best adapted to local conditions. Generally speaking, scientific evidence and managers' experience have shown that there are only two options of social response to rising sea level: either resistance by building coastal defence structures, a costly and environmentally ill-adapted solution, or adaptation by receding, which involves strict land use regulation often difficult to implement but environmentally by far more convenient. Paskoff shows clearly his preference for the latter option by suggesting to persuade actors and users of the coastal space that in a context of rising sea level both society and nature have only to gain by allowing the coastal natural environment to occupy the available space needed for ensuring its undisturbed natural evolution as well as its sustainability and attractiveness ${ }^{40}$.

Accordingly, while discarding an excessively alarmist evaluation of the risks of rising sea level, Paskoff stressed the need for taking appropriate defensive measures in accordance with the precautionary principle, stating in his conclusion of the cited conference proceedings that "One should not dramatize the expected impacts of global rising sea level anticipated for the coming century, but the precautionary principle implies that they should not be ignored and that measures susceptible to mitigate their consequences for society have to be taken by now" ${ }^{41}$.

More recent reflections shading light on interesting developments in the conceptual evolution of coastal geography are presented in a recently-published collection of papers dealing with risk management of various coastal zones ${ }^{42}$. Of special interest is the reflection on the issue of coastal vulnerability to adverse

\footnotetext{
40 R. PAskofF, Le changement climatique..., 5.

${ }^{41}$ R. PASKOFF, Le changement climatique ...

42 J.-M. Miossec et alii, "Editorial: Le littoral, caractérisation et gestion d'un espace à risques”, in F. LÉONE, F. VINET (dir.), Géorisques 4, 2013, 9-11.
}

"Insights on the emergence and conceptual evolution of coastal geography ..." 
impacts of various natural hazards and extreme events related to violent assaults of the sea on coasts. There is a clear tendency to attribute the extent of the damage caused to users of the coasts to the intensity of their anthropization rather than to the violence of natural forces. This observation has significant implications for evaluation of the role of climate change as regards increased coastal vulnerability. While still recognizing the reality of global warming and its role in rising sea level, this role is alleged to be only a contributing factor, alongside other significant natural factors such as eustatism, in the phenomenon of receding coasts. Whatever are the causes of climate change, the responsibility towards damage inflicted by its impacts to users of the coastal space is thus attributed mainly to imprudent use of this space.

This vision has far-reaching implications as to the evaluation of natural risks and related damage inflicted to users of the coastal space. An interesting analysis of the notions of natural risk and related damage from the geographer perspective is provided by Patrick Pigeon ${ }^{43}$. He proposes the following definition of natural risk: "The probability of damage occurrence considering the interactions between damaging physical processes (hazards) and human settlement factors (vulnerability)". Accordingly, these interactions determine the damage, including the preventive and corrective measures intended to manage it. The notion of risk appears thus to entail two components: that of potential damage and that of effective damage as perceived by society. Vulnerability is defined as follows: "Human settlement factors contributing in an unequal manner to the occurrence of damage" 44 . However, in this analysis vulnerability to environmental change, notably that related to rising sea level, is not conceived of in absolute terms to the extent it is recognized as a social construct depending

43 P. Pigeon, "Réflexions sur les notions et les méthodes en géographie des risques dits naturels", Annales de géographie 627-628, 2002, 452-470.

44 Ibid., 460-461. 
considerably on users' stakes and perceptions as well as on the time scale used for its observation ${ }^{45}$.

The issue of evaluating climate change risk factors and liability for damage inflicted to coastal populations by global worming induced rising sea level has been given in international forums a growing attention in recent years ${ }^{46}$. Poor countries with extensive and often densely populated coastal areas claimed compensation for damage inflicted by global worming induced rising sea level, alleging to be victims of greenhouse gases emissions by industrialized countries. The discussion of this complex issue indicates the need for in-depth analysis of such notions as vulnerability and environmental risk.

The analysis of the interactions between natural factors and human factors of environmental risk has significant implications for determining the extent of eventual compensation for coastal populations adversely affected by rising sea level. Incidentally, it also shows the relevance of the developing field of "geography of environmental risks and human security" for coastal geography in the conceptual framework of which it may find a respectable place.

\section{Conclusion.}

Coastal geography has undergone in France a very significant evolution since its emergence in the early 1950s. This reflected the growing interest for its object of study - the coastal space, the increasing attractiveness of which resulted in increased vulnerability. Initially focused on the study of the physical geography of the coastal space, coastal geography broadened significantly its scope by integrating human geography in order to adapt to the changing nature of the coastal space with its growing anthropization and the accelerated environmental change induced

\footnotetext{
45 J.-M. MiossEC et alii, "Éditorial: le littoral ...”, 9.

46 Elly Hermon, "Climate Change Related Loss and Damage: Conceptualization and Implications”, Cosmopolis, 2013/1.

"Insights on the emergence and conceptual evolution of coastal geography ..."
} 
by human activities as well as by natural factors, among which climate change played a significant role. This encouraged the adoption of the global geography approach, widely open to integration of various areas of study dealing with the numerous aspects of the issue area of the costal space and to interdisciplinary perspectives. Its emphasis on Man-Nature relations and the growing need for well-informed interventions aimed at improving the management of coastal areas brought to increasing involvement of geographers in the area of coastal management, a responsibility previously conferred to practitioners often lacking proper understanding of the natural processes affecting coastal areas. The broad vision of the problems affecting these areas and of the related interactions between society and the natural environment allowed coastal geographers to play a significant role in advancing the integrated management of the coastal space and to influence decision-makers and society at large to support adoption of coastal management policies more in line with protection of the coastal natural environment.

The involvement of coastal geographers in the area of environmental risk management is a promising development. They are well prepared to bring a valuable contribution to the advancement of this developing field much needed for adequately dealing with serious problems affecting coastal areas with a growing intensity. Their expertise associating good understanding of the coastal natural environment and of the vulnerability of human settlement there, as well of the interactions between both issues, confer them a privileged position for contributing to the search for relevant solutions for coping with complex challenges such as those related to global warming induced sea level rise expected to become a major concern for still larger populations than those currently affected. 
E. HERMON

\section{Bibliography.}

E.C.F. BIRD, Coastline Changes. A Global Review, Chichester 1985.

J.-P. CORLAY, "Géographie sociale, géographie du littoral", Norois 42, 165, 1995, 247-265.

A. GUILCHER, Morphologie littorale et sous-marine, Paris 1954.

A. GuILCHER, "Développement de la notion de gestion des littoraux chez les géographes français", in Régions, villes et aménagement. Mélanges jubilaires offerts à J. Beaujeu-Garnier, Paris 1987.

A. GuILCHER, "Vers une philosophie des rivages", Cahiers Nantais 3536,1990, 3-15.

E. HERMON (dir.), Riparia dans l'empire romain, pour la définition du concept, Oxford 2010.

E. HERMON, A. WATELET (dir.), Riparia, un patrimoine culturel. La gestion intégrée des bords de l'eau, Oxford 2014.

Elly Hermon, "Climate Change Related Loss and Damage: Conceptualization and Implications", Cosmopolis 2013/1 http://www.cosmopolis-rev.org/en

C. MEUR-FÉREC, De la dynamique naturelle à la gestion intégrée de l'espace littoral: un itinéraire de géographe, Université de Nantes (HDR), 2006 http://hal.archivesouvertes.fr/docs/00/16/77/84/PDF/essai_inedit Meur-Ferec.pdf $(01 / 08 / 2014)$.

A. Miossec, "Aménagement et milieux naturels: le littoral français entre ruptures et continuités”, Cahiers Nantais 47-48, 1997.

A. MiosseC, Les littoraux entre nature et aménagement, Paris 1998.

J.-M. MIOSSEC et alii, "Éditorial: Le littoral, caractérisation et gestion d'un espace à risques", in F. LÉONE, F. VINET (dir.), Géorisques 4, 2013, 9-11.

R. PASKOFF, Les littoraux, impacts des aménagements sur leur évolution, Paris 1985.

R. PASKOFF (coord.), Le changement climatique et les espaces côtiers. L'élévation du niveau de la mer: risques et réponses. Actes du colloque d'Arles, 12-13/10/2000, Paris 2001.

R. PASKOFF, "Le changement climatique, l'élévation du niveau de la mer et les espace côtiers: synthèse et perspectives", in R. PASKOFF (coord.), Le changement climatique et les espaces côtiers. L'élévation du niveau de la mer: risques et réponses. Actes du colloque d'Arles, 12-13/10/2000, Paris 2001.

R. PASKOFF, "La contribution des géographes naturalistes à la géographie des littoraux”, Océans 28(1-2), 2002, 27-38.

"Insights on the emergence and conceptual evolution of coastal geography ..." 
RIPARIA VOL. 0 (2014)

P. PigEON, "Réflexions sur les notions et les méthodes en géographie des risques dits naturels", Annales de géographie 627-628, 2002, 452-470. J.-P. PINOT, "Géographie des littoraux en France: évolution d'une discipline", in Le littoral, regards, politiques et savoirs. Études offertes à Fernand Verger, Paris 2002.

UNESCO, Methodological Guide to Integrated Coastal Management, Intergovernmental Oceanographic Commission, Manual and Guides No.36, 1997.

F. VERGER, "Les risques liés à l'élévation du niveau de la mer dans les marais maritimes et les polders", in R. PASKOFF (coord.), Le changement climatique et les espaces côtiers. L'élévation du niveau de la mer: risques et réponses. Actes du colloque d'Arles, 12-13/10/2000, Paris 2001. 